\title{
Level of compliance with the requirements of corporate social responsibility in Czech enterprises
}

\author{
Zdenka Hofbruckerová1,*, Petra Halfarová ${ }^{1}$, and Andrea Uherková $^{1}$ \\ ${ }^{1} \mathrm{VŠB}$ - Technical University of Ostrava, Department of Quality Management, 17. listopadu 15/2172, \\ 70833 Ostrava - Poruba, Czech Republic
}

\begin{abstract}
Corporate Social Responsibility (CSR) concept is focused on understanding and managing the impacts a company has on the world around it, and doing so as a part of core business activities. CSR contains three parts: Profit (economical part), People (social aspects - employees and stakeholders) and Planet (environment). The papers deal with basic features, objectives and outputs of CSR concept in practical life of Czech enterprises. The main aim of the research was to define if organizations referring themselves as socially responsible do implement activities of all the three pillars equally and integrate them into their day-to-day activities.
\end{abstract}

\section{Introduction}

The most companies nowadays practice some form or part of Corporate Social Responsibility concept (CSR). The goal of the paper is to analyse if organizations participating on Governor Award for Social Responsibility and Social Responsibility Poll in Moravian - Silesian Region know and are able to interpret required aspects in all three pillars of CSR management system according to ČSN 010391 standard in parallel.

\subsection{Corporate Social Responsibility}

Corporate social responsibility (CSR) is voluntary organization's initiative to assess and take responsibility for the company's effects on environmental management, economical growth and social progress. The term generally applies to efforts that go beyond law requirements with respect to communication with stakeholders. The concept of social responsibility of organizations is built on three pillars, which are collectively referred to as the triple bottom line (TBL) or 3P strategy. They are: Profit / economic, People / social and Planet / environmental area. The areas represent a threefold overall impact of business on society. [1] That shows that it is possible to achieve positive financial results, which lead to a reduced impact on the environment and society without dealing additional damage [2]. This attitude are accepted all around the world for example in India [3], Greece [4] or in Italy [5].

\footnotetext{
* Corresponding author: zdenka.hofbruckerova@vsb.cz
} 


\section{2 ČSN $010391: 2013$}

ČSN 010391 is a national Czech standard issued in 2013 which specifies requirements for the management system of social responsibility. The standard tries to offer the way how to integrate CSR management system requirements for the individual pillars (economic, environmental and social) and requirements for improvement (in accordance with the PDCA cycle). Standard can be used for certification on the national level. This standard is most suitable for organizations that has already implemented any management system (according to ISO 9001, 14001, OHSAS), as corresponds to the different chapters of these international standards. Appropriate chapters and the similar structure can help organizations to transform requirements of CSR according to ČSN 010391 to existing integrated management system easier [6].

\subsection{Award of Governor for Social Responsibility and Social Responsibility Poll}

Governor of Moravian - Silesian Region together with Quality Council of Czech Republic announces Award for Social Responsibility since 2009. The aim of the competition is to appreciate the companies, public sector organizations and municipalities activities in the Moravian-Silesian Region in the field of corporate social responsibility. The competition is divided into categories:

- business entities (businesses) up to 50 employees, from 51 to 250 employees, over 250 employees,

- public sector organizations: up to 50 employees, over 50 employees,

- municipality: municipalities with extended competences, other municipalities.

Social Responsibility Poll participants were nominated by the public and employees as the social responsible organizations and therefore it is likely that the CSR concept is part of their strategic focus.

\section{Backgrounds}

The issue of corporate social responsibility is now becoming an increasingly important part of strategic planning and business development. The cause is in particularly increasing consumer pressure to take responsibility for the level of social, environmental and economic impacts of corporate activities and expectations towards producers, service providers as well as public administration organizations or educational institutions.

The concept of corporate social responsibility can be an opportunity to further develop the organization after the introduction of a quality management system or an integrated management system and thereby become another element of the organization's competitiveness [7].

However, it is a fact that organizations are not making full use of their potential in the field of CSR implementation. Organizations often do not know the essence of the concept of CSR and for that reason it is not included in their strategic development plans. Also there are many aspects that management perceives as significant barriers to introducing CSR in a complex (three-pillar) form. Organizations independent of size indicate as ones of the main barriers the fact, that CSR activities do not affect the customers preferences and do not differ organization from competition and on the other side cause the limitation of profit maximalization and higher costs of realization of CSR activities [8]. However, these organizations have not mapped the possibilities of overcoming these barriers. According to many researches, it is possible to say that customers prefer organizations that declare and 
can prove their social responsibility. [9] Equally, it is possible to obtain funding for the implementation of CSR programs from EU funds. [10]

The main aim of the research is to define if organizations referring themselves as socially responsible do implement activities of all the three pillars equally.

The respondents were chosen from all organizations that participated in Social Responsibility Poll (promulgated by Institute for Social Responsibility) or applied in the evaluation for Award for CSR in Moravian-Silesian Region from 2010 to 2014. This target group was chosen intentionally because participated organizations are likely that the CSR concept is part of their strategic focus.

\section{Survey}

On the basis of literature studies, informal interviews with managers of different types of organizations, and experience with organizational assessment in terms of meeting CSR requirements, the following hypothesis has been specified:

Companies participated in Award of Governor for Social Responsibility and Social Responsibility Poll meet the requirements of all three pillars of CSR in a mutual balance (from more than $70 \%$ in each researched pillar).

Data for verifying were gained in an empirical survey by the questioning. Questionnaires was designed in google application and only prolink to it was sent to the email addresses of organization heads, top manager, PR managers and other managers from September to December 2016. 114 respondents from 336 companies answered in the survey, which is a return of $34 \%$. The respondent group consisted of $21,05 \%$ small (less than 25 employees), $36,84 \%$ middle and $42,11 \%$ big (more than 250 employee) companies. Service enterprises had the biggest share $(61,54 \%)$, production companies built more than one fifth $(20,51 \%)$ and organizations of public sector were represented by $17,94 \%$.

The questionnaire was designed according to requirements of ČSN 010391 standard to the three pillars of CSR (social, environmental and economic pillar). Individual questions and positive responses are shown in Table 1.

Table 1. Formatting sections, subsections and subsubsections.

\begin{tabular}{|l|l|l|}
\hline Pillar & Question & $\begin{array}{l}\text { Positive } \\
\text { responses }\end{array}$ \\
\hline Social pillar & Do you verify compliance of CSR rules in your suppliers? & $23,08 \%$ \\
\cline { 2 - 3 } & $\begin{array}{l}\text { Have you created a pay system for work, a system of benefits } \\
\text { and extraordinary rewards? }\end{array}$ & $\mathbf{9 7 , 4 4 \%}$ \\
\cline { 2 - 3 } & Do you take into account in some way the work-life balance? & $64,10 \%$ \\
\cline { 2 - 3 } & Do you support a local community? & $\mathbf{7 1 , 7 9 \%}$ \\
\cline { 2 - 3 } & $\begin{array}{l}\text { Do you ensure consumer protection by providing complete and } \\
\text { comprehensible product information? }\end{array}$ & $\mathbf{9 1 , 8 9 \%}$ \\
\cline { 2 - 3 } & $\begin{array}{l}\text { Do you provide consumer protection by providing complete } \\
\text { information on warranty and dealing with complaints and } \\
\text { disputes? }\end{array}$ & $\mathbf{8 5 , 2 9 \%}$ \\
\cline { 2 - 3 } & Have you set up a system for protecting consumer privacy? & $\mathbf{8 1 , 0 8 \%}$ \\
\cline { 2 - 3 } & $\begin{array}{l}\text { Can you prove that the organization does not practice unfair } \\
\text { commercial practices? }\end{array}$ & $\mathbf{1 0 0 , 0 0 \%}$ \\
\hline \multirow{2}{*}{$\begin{array}{l}\text { Envilianmental } \\
\text { pillar }\end{array}$} & $\begin{array}{l}\text { Do you identify the environmental aspects (those that have or } \\
\text { may have an impact on the environment) for existing activities } \\
\text { and products? }\end{array}$ & $\mathbf{7 1 , 4 3 \%}$ \\
\cline { 2 - 3 } & $\begin{array}{l}\text { Do you identify environmental aspects for planned, new and } \\
\text { changed activities and products? }\end{array}$ & $57,14 \%$ \\
\cline { 2 - 3 } & Have you determined the significance of the identified & $51,52 \%$ \\
\hline
\end{tabular}




\begin{tabular}{|l|l|l|}
\hline \multirow{5}{*}{} & environmental aspects? & \\
\cline { 2 - 3 } & Are you trying to minimize emissions in product management? & $\mathbf{8 5 , 2 9 \%}$ \\
\cline { 2 - 3 } & $\begin{array}{l}\text { Are you trying to minimize the potential for interference in } \\
\text { product management? }\end{array}$ & $32,35 \%$ \\
\cline { 2 - 3 } & $\begin{array}{l}\text { Are you trying to minimize the consumption of feedstock and } \\
\text { energy in product management? }\end{array}$ & $\mathbf{7 3 , 5 3 \%}$ \\
\cline { 2 - 3 } & $\begin{array}{l}\text { Are you trying to minimize waste generation in product } \\
\text { management? }\end{array}$ & $55,88 \%$ \\
\hline \multirow{5}{*}{\begin{tabular}{l} 
Economillar \\
\cline { 2 - 3 }
\end{tabular}} & $\begin{array}{l}\text { Do you evaluate the suppliers also on the basis of his / her } \\
\text { eligibility to comply with the principles of corporate social } \\
\text { responsibility? }\end{array}$ & $41,03 \%$ \\
\cline { 2 - 3 } & Do you have a procedure for identifying stakeholders? & $45,49 \%$ \\
\cline { 2 - 3 } & Have you set ethical principles towards stakeholders? & $59,46 \%$ \\
\cline { 2 - 3 } & $\begin{array}{l}\text { Do you have a procedure for recording the findings of non- } \\
\text { compliance with ethical principles? }\end{array}$ & $30,56 \%$ \\
\cline { 2 - 3 } & Are you planning investments into the community? & $41,03 \%$ \\
\cline { 2 - 3 } & Do you maintain your current community status listings? & $30,77 \%$ \\
\cline { 2 - 3 } & Do you employ workers from the surrounding community? & $43,59 \%$ \\
\cline { 2 - 3 } & $\begin{array}{l}\text { Do you select suppliers mainly from the surrounding } \\
\text { community? }\end{array}$ & $33,33 \%$ \\
\cline { 2 - 3 } & $\begin{array}{l}\text { Do you report the fees and penalties applied to your } \\
\text { organization? }\end{array}$ & $\mathbf{7 6 , 9 2 \%}$ \\
\hline
\end{tabular}

Each pillar was evaluated separately, respectively answers to its questions were evaluated separately. As a question that meets the majority requirement in a given pillar, a question has been included in which the percentage of positive responses exceeds $70 \%$. If these questions (with a positive response rate of more than 70\%) in a particular pillar were more than $70 \%$, it was possible to argue that the pillar was fulfilled with the majority of requirements. If all three pillars of CSR have been fulfilled, then it was possible to argue that companies meet most (more than 70\%) the requirements of all three pillars of CSR.

\section{Results Analysis}

Survey in the area of the social pillar was based on the eight requirements according to CSN 010391 standard. Six of them crossed the positive response threshold above $70 \%$. The average percentage of positive responses for these requests is relatively high, namely $87.3 \%$. In percentage terms, this means that the social pillar was filled by a total of $75 \%$. Therefore, it can be argued that companies fulfill the majority requirements of the social pillar.

The area of environmental pillar research consisted of seven requirements, but only three of them have exceeded the $70 \%$ threshold. They were focused on the identification of environmental aspects for existing activities and products, as well as efforts to minimize the impact from the point of view of emissions and, finally, efforts to minimize the consumption of feedstock and energy. The average percentage for these three positive responses was $76.8 \%$. Since the set seventy percent threshold exceeded only three of the seven requirements, this pillar was only filled by $42.9 \%$. It is necessary to say that this pillar, from the point of view of majority fulfillment, has not been fulfilled.

The economic pillar requirements were formulated in nine questions, but only one requirement exceeded $70 \%$ in the percentage of positive responses. This requirement concerned the recording of fees and sanctions applied to the organization. Unfortunately, the remaining eight requirements were below 60 percent of the positive response, even seven requests were only under the 50 percent threshold. Therefore, it should be noted that 
this pillar has not been met from the point of view of the majority fulfillment of requirements. The results of meeting the requirements of all three pillars are shown in the Table 2 .

Table 2. Comparison of the fulfillment of the requirements of the individual CSR pillars.

\begin{tabular}{|c|c|}
\hline Pillar & Fulfillment \\
\hline Social & $75.00 \%$ \\
\hline Environmental & $42.90 \%$ \\
\hline Economic & $27.27 \%$ \\
\hline
\end{tabular}

Therefore, the hypothesis was not fulfilled. Based on the questionnaire survey, it is not possible to claim that companies fulfill most (more than 70\%) the requirements of all three pillars in the field of CSR in mutual balance. It can be argued that companies fill the most of requirements only in social pillar. The mutual balance in all three pillars is met only in $27.27 \%$ of organizations.

\section{Conclusion}

In general, based on the findings, it is possible to state that organizations claiming the concept of corporate social responsibility do not fulfill the prerequisite for a comprehensive fulfillment of the requirements of all three pillars in mutual balance. The least attention is paid to the economic pillar. Most of the organizations surveyed $(75 \%)$ perform the social pillars in particular in relation to employees. This fact follows from the historical development of the concept of CSR in our environment, when a certain form of employee care was implemented even during the socialist regime. On the contrary, the requirements that the other pillars include in the current concept of CSR have not been taken into account at all. However, the motives for increased effort for employee welfare were different from those of the present. While today organizations are primarily concerned with maintaining reliable, educated and loyal employees as carriers of corporate development, in the past, it was essential to keep staff satisfied with the aim of eliminating the causes of social unrest and suppressing activities that were not in line with the socialist way of government management. In spite of this pejorative insight, the expectations of high-level employees remain high, and this is the cause of a large number of activities in the area of the internal social pillar as declared by the concept of CSR.

Similarly the imperfect implementation of the economic pillar can be explained. In today's business environment corruption is unfortunately still a common phenomenon, secondary insolvency destroys small entrepreneurs, and big companies are unable to get a big order without bribes. It is very difficult to appeal to the ethical principles of business when their (not) adherence is often dependent on existence and thus on jobs. Similarly, it is difficult to comply with the invoice maturity if the tax burden is so high and the maturity dates from customers are often shifted beyond the 3 months.

The ecological pillar seems to be the least interesting in this respect, as the vast majority of environmental measures commonly adopted by organizations are part of legislative codification. Organizations from ignorance of other options do not show an interest in further raising the level of the environmental pillar.

It is possible to claim that only one quarter $(27.27 \%)$ of the surveyed organizations referred themselves as socially responsible fulfil all requirements of Czech national standard for corporate social responsibility ČSN 010391 in mutual balance. 
In conclusion, it is a competitive advantage of the addressed organizations that many of the above-mentioned CSR requirements are already implemented, although not yet implemented in their complex form. This is a good starting point from which organizations can profit if they are willing to work equally to implement the requirements of all three pillars.

\section{Acknowledgements}

This paper was elaborated in the frame of the specific research project SP2018/97, which has been solved at the Faculty of Metallurgy and Materials Engineering, VŠB-TU Ostrava with the support of Ministry of Education, Youth and Sports, Czech Republic.

\section{References}

1. R. Petříková, Z. Hofbruckerová, P. Hercík, R. Lešingerová, Společenská odpovědnost organizací (DTO CZ, Ostrava, 2008)

2. A. McWilliams, D. Siegel, Strategic Management Journal, 21, 5 (2000)

3. S. Maqbool, M. N. Zameer, Future Business Journal, 4, 1 (2018)

4. A. G. Sahinidis, D. Daskalaki, E. Mantzari, I. Mantzaris, Suistainability and Social Responsibility: Regulation and Reporting (2017)

5. M. Costa, P. Torrecchia, Corporate Social Responsibility and Environmental Management, 25, 2 (2017)

6. Z. Hofbruckerová, P. Halfarová, T. Divinová, Metal, 25 (2016)

7. Š. Markulík, L. Kamenický, J. Namešanská, A. Nagyová, Advances in Physical Ergonomics and Human Factors (2014)

8. Z. Hofbruckerová, T. Divinová, Współczesne problemy ekonomii - między teorią a praktyką gospodarczą, 1 (2016)

9. J.J. Rivera, E. Bigne, R. Curras-Perez, Spanish Journal of Marketing, 20, 2 (2016)

10. J. Koštálová, L. Tetřevová, Metal, 25 (2016) 